\title{
INTERNATIONAL LAW AND Actual Issues IN Viet NAM
}

\author{
Edited by Nguyen Hong Thao \\ (Viet Nam Society of International Law/Youth Publishing House, 2019), \\ $368 \mathrm{pp}$. \\ ISBN: 978-604-204-6
}

\section{Le Thi Ngoc Mai*}

The book titled, InTERNATIONAL LAW AND Actual Issues IN VIET NAm is a collection of articles related to legal regulations and international law enforcement practices in Vietnam. The book was compiled by Professor Nguyen Hong Thao as Editor-inChief of the Vietnam Society of International Law. Professor Nguyen Hong Thao serves as Vice Chairman of the United Nations International Law Commission and is an expert in international public law, environmental law, maritime law, and border demarcation, with nearly 40 years of legal and diplomatic work experience. Professor Nguyen has also served as Deputy Chairman of Vietnam's National Border Committee and Ambassador to Malaysia, participated in numerous delegations on territorial border disputes, and is the author of several scholarly books and newspaper articles on international law.

The two main focuses of the book involve the law of the sea and international investment law. Five articles in the book focus on the law of the sea, because "sovereignty" of the South China Sea has been a highly disputed diplomatic issues between Vietnam and China. The issues related to the law of the sea are written from a legal and practical perspective. The legal issues are discussed in three articles, which begin with Professor Nguyen's overview of the 1982 United Nations Convention on Law of the Sea and its role in the development of Vietnam's legal system in his

* Lecturer at Hanoi Law University (Economic Law), Vietnam; Ph.D. researcher at Zhejiang University, Hangzhou, China. The reviewer may be contacted at:1tnmai@moj.gov.vn. 
article titled, 25th Anniversary of the 1982 UNCLOS and Its Implementation in Vietnam. In a second article by Quoc Phap, the author clarifies legal issues related to the South China Sea disputes between China and its neighboring countries in an article titled, Nine-dashed Line: An Illegal Claim in Bien Dong. The author then compares provisions in international law with a 1958 diplomatic note that allegedly recognized China's sovereignty over the South China Sea, ultimately refuting China's claims in an article titled, Whether the Socialist Republic of Vietnam is Bound to the 1958 Note?

The next two articles then discuss the issue of international law enforcement on the South China Sea in: (1) Arbitration Between the Philippines and China concerning the South China Sea Dispute: Content of the Award and Its Legal Value (Pham Lan Dung and Tran Huu Duy Minh); and (2) Development of maritime law enforcement forces in the South China Sea-Vietnamese case (Nguyen Hong Thao). The terminology used in these two articles is inconsistent, e.g., sometimes the East Sea (Bien Dong) and the South China Sea are used interchangeably.

In addition to maritime disputes, Vietnam, like many other countries in the world, has a strong interest in international law related to investment in particular and economy in common. Vietnam is a country located within an important geopolitical position in Southeast Asia, with its long coastline and point of international transit. As such, Vietnam is a destination attractive for foreign investment. Vietnam has been a WTO member since 2006 and participated in many other international agreements. In recent years, practice has unveiled numerous investment disputes. Three articles analyze resolving international investment disputes, two from a general international law perspective: (1) Concerns Regarding The Investor-State Dispute Settlement (ISDS) and the Global Trends of ISDS Reform (Le Thi Tuyet Mai); and (2) Mediation-A Trend For Commercial Dispute Resolution in the Integration Period (Nguyen Hung Quang), while the third article titled, To Sign or Not to Sign? A Conundrum of Vietnam's Accession to the ICSDS (Chau Huy Quang and Umut Turksen) discusses current legal issues Vietnam.

In addition, two other economic issues discussed are environmental law and the protection of intellectual property, within the boundaries of Vietnam's international responsibilities. In the Evoluntionary Interpretation of GATT Article XX by GATTMTO Adjudicating Bodies: Towards a Trade-Environment Reconciliation, Ly Van Anh and Dinh Thi Phuong Anh clarify the practice of explaining phrases through specific cases that were resolved by the WTO, such as the US (gasoline, shrimp, gambling), European council (seals, asbestos), Thailand (Tobacco), and South Korea (beef). In Perspective of the Intellectual Property (IP) and the Agreement on Trade-Related Aspects of IPR (TRIPS), Nguyen Hong Thao claims that current practices and new technological development will require revising the TRIPs Agreement, in particular: (1) extending the transitional 
period of implementation of the TRIPs Agreement; (2) the relation between the TRIPs Agreement and the Convention on Biodiversity; and (3) E-commerce.

The final article is devoted to human rights titled, Holding International Organizations Responsible for Violating International Human Rights Law: Obstacles and Recommendations (Pham Van Trung). This article does not discuss Vietnam specifically, but clarifies the main difficulties of international law in determining the scope of international obligations to protect human rights, as well as obstacles in resolving complaints against international organizations due to violations of international human rights laws through a series of specific cases and recommendations.

This book was published by compiling collective experience from top Vietnamese scholars for a better understanding of the major international law-related issues in Viet Nam today. It can provide the insight to readers wishing to know more about current legal practices as well their profound implications for Vietnam.

Received: August 1, 2020

Modified: October 30, 2020

Accepted: November 15, 2020 
